\title{
ENVIRONMENTAL EDUCATION FOR ENVIRONMENTAL JUSTICE IN THE SCHOOL CONTEXT: TEACHERS DISCOURSES AND PRACTICES
}

\author{
Angélica Cosenza ${ }^{1}$ \\ Isabel Martins ${ }^{2}$
}

\begin{abstract}
In this article we discuss meanings made by a teacher during the didactic treatment of a socioenvironmental conflict in Biology classes. The environmental conflict in question involves environmental injustice processes and results from the territorial dispute involving official institutions and a community in the neighboring region of a national park that is located by a Brazilian city that was severely impacted by the growth of the oil indudtry. This work is framed by critical discourse studies (Critical Discourse Analysis - CDA) and privileged intertextuality as an analytical dimension, which suggests ways through which other texts are explicitly marked on the textual surface. Our analyzes suggest that by enunciating pedagogical practices related to environmental injustice processes, the teacher establishes ambivalent relations between conservative and emancipatory discourses of environmental education. This study argues for the discussion of the political dimensions of environmental education in school, giving visibility to acute processes of environmental injustices as well as to both the struggles and protagonism of communities in this process.
\end{abstract}

Keywords: Environmental Justice. Critical Discourse Analysis. School

\section{EDUCACIÓN AMBIENTAL PARA LA JUSTICIA AMBIENTAL EN EL CONTEXTO ESCOLAR: DISCURSOS Y PRÁCTICAS DOCENTES}

\section{Resumen}

En este artículo discutimos las significaciones de una profesora sobre el tratamiento didáctico de un conflicto socioambiental, en las clases de biología. El conflicto ambiental que interesa a este estudio involucra procesos de injusticia ambiental y deriva de la disputa territorial, que involucra a organismos oficiales y una comunidad en región limítrofe al Parque nacional cerca de una ciudad que fué severamente afectada por el crescimiento de la industria del petroleo. Este trabajo se apoyó en los estudios críticos del discurso (ACD) y privilegió la intertextualidad, manifiesta como dimensión analítica, que sugiere formas por las cuales otros textos están explícitamente marcados en la superficie textual. Nuestros análisis sugieren que al enunciar prácticas pedagógicas relacionadas a procesos de injusticias ambientales, la profesora establece relaciones ambivalentes entre discursos conservadores y emancipatorios de la educación ambiental. Este estudio se sitúa en la defensa y opción por explotar dimensiones políticas de la educación ambiental en la escuela, partiendo de la visibilidad a procesos agudos de injusticias ambientales, así como luchas y protagonismos comunitarios.

Palabras clave: Justicia ambiental. Análisis Crítico del Discurso. Escuela.

\footnotetext{
${ }^{1}$ Doutora em Educação em Ciências e Saúde pela Universidade Federal do Rio de Janeiro, Professora Dra. da Faculdade de Educação e do Programa de Pós-graduação em Educação PPGE/FACED/UFJF da Universidade Federal de Juiz de Fora. Grupo de Estudos e Pesquisas em educação Ambiental GEA/UFJF. ar_cosenza@hotmail.com

${ }^{2}$ Doutora em Educação pela Universidade de Londres, Professora Titular do Núcleo de Tecnologia Educacional para a Saúde da Universidade Federal do Rio de Janeiro. isabelmartins@ufrj.br
} 


\title{
EDUCAÇÃO AMBIENTAL PARA JUSTIÇA AMBIENTAL NO CONTEXTO ESCOLAR: DISCURSOS E PRÁTICAS DOCENTES
}

\begin{abstract}
Resumo
Neste artigo discutimos as significações de uma professora sobre o tratamento didático de um conflito socioambiental, em aulas de biologia. O conflito ambiental que interessa a este estudo envolve processos de injustiça ambiental e decorre da disputa territorial, que envolve órgãos oficiais e uma comunidade em região limítrofe a um parquet nacional localizado nas vizinhanças de uma cidade brasileira severamente impactada pelo crescimento da indústria do petróleo. Este trabalho apoiou-se nos estudos críticos do discurso (Analise Crítica do Discurso - ACD) e privilegiou a intertextualidade, manifesta como dimensão analítica, que sugere formas pelas quais outros textos estão explicitamente marcados na superfície textual. Nossas análises sugerem que, ao enunciar práticas pedagógicas relacionadas a processos de injustiças ambientais, a professora estabelece relações ambivalentes entre discursos conservadores e emancipatórios da educação ambiental. Este estudo situa-se na defesa e opção por explorar dimensões políticas da educação ambiental na escola, partindo da visibilidade a processos agudos de injustiças ambientais, bem como lutas e protagonismos comunitários.
\end{abstract}

Palavras-chave: Justiça ambiental. Análise Crítica do Discurso. Escola.

\section{INTRODUCTION}

In this work, which relies on critical discourse studies, we discuss meanings made a high school teacher at a public state school in a Brazilian city that was severely impacted by the growth of the oil indudtry. about the didactic treatment of a socio-environmental conflict in biology classes. Her proposal emerges in the context of a continuing formation process which included the production and development of didactic sequence about energy under the project Science Education: Performance of students, educational practices and teaching materials ${ }^{3}$.

The project aimed at a shift in Biology pedagogical practice, regarding the treatment of the theme energy, while seeking to relate it to discussions on environmental justice ${ }^{4}$ and local environmental conflicts in a school located in a region marked by socio-historical processes of occupation by a large oil industry. Such processes also involved the eviction of groups of the local population leading to brutal changes in this space, of which many students are victims.

Social and environmental consequences of large infrastructure projects involved in the oil production chain have been highlighted in a number of disrespectful practices, sociocultural violence and environmental injustice ${ }^{5}$ (FILHO et al, 2010). Such practices are the

\footnotetext{
${ }^{3}$ This project was developed between 2009 and 2012 and was funded by the Brazilian Ministry of Education through the call "Education Observatory" (CAPES/INEP/SECAD 2008-1) and by CNPq (Brazilian Research Council).

${ }^{4}$ The concept of environmental justice arises in the framework of the movement for environmental justice as one of the trends of the contemporary environmental movement. It can be defined according to Bullard (2004) from situations in which the burden of environmental developmental damage is concentrated predominantly among poorer populations and in their living places.

${ }^{5}$ The concept of environmental injustice defines the situations in which the burden of environmental developmental damage is concentrated predominantly among poorer populations and in their living places. A
} 
result of a production system, land occupation, destruction of ecosystems, spatial allocation of polluting processes, which penalize the living conditions of the population living in poor neighborhoods, sometimes "slumized", and excluded from the big "oil dream".

Considering this context, the competence and the ability to critically analyze the environmental, social and economic implications of the use of processes of energy resources was listed as a curricular goal, in the context of the activities of project above mentioned. Such activities explores the extent to which the didactic treatment of an environmental conflict could promote education for environmental justice. The search for this relationship was a challenge made to the teacher, who in turn responded positively indicating a very conflictive situation in a place where some of her students lived. In this place, situated in the neighboring territory of a national park, where there is a conflict, involving about 150 lowincome families. They have lived there for last decade theough basic public services, such as clean water and collection of sewage, are not available.

The described conflict polarizes territorial occupation versus conservation of natural resources and confronts the interests of conservationist and environmental justice groups. Besides the residents and park managers, the conflict involves institutional actors such as the Federal Public Ministry, the municipal authority, and social and neighborhood collective movements. In this context, conflicting views about the presence of the families in the area coexist: there are groups who are against the presence of the families in the area while others support their permanence and their right to land, as they are considered a minimum buffer zone of the protected area. In general, this conflict is constituted of different interests and needs disputed about the occupation and use of densely and disorderly occupied territories after the establishment of exploitative activities of oil and gas in the region.

In order to explore meanings from this environmental conflict in the constitution of a teaching practice focused on the promotion of education for environmental justice, we delimit here two discursive events to be discussed. The first one presents oral discourses of the teacher in the context of discursive interactions with high school students, when developing an educational activity. The second one consists of a text, written by the teacher as the final report on the project's activities, which gathers reflections and evaluative comments of her practice, thus providing fertile ground for the analysis of the ideological work of the speech.

This study argues for the discussion of the political dimensions of environmental education, in connection with citizenship and environmental justice, and seeks to contextualize and politicize the environmental debate and discuss the contradictions of development models and society experienced locally and globally.

We understand that although there is a consensus on the importance of addressing environmental issues at school, on the other hand, there are different political and ideological representations of what environment is and the nature of its importance in the school curriculum (LAYRARGUES; LIMA 2011). These representations, which may mask environmental conflicts or bring them to the surface, illustrate the importance of processes, through which the teacher presents the environmental conflict and incorporates it into her teaching. The absence or reduced presence of environmental conflicts in pedagogical practice takes a semiotic expression in school curricula, in the discourse of teachers and students, and can be investigated through the discourses of those who are protagonists in the studied social processes.

logic that makes all the harmful effects of development always fall on the most vulnerable populations (ACSELRAD; MELLO, 2009). 
We start from the understanding that the suppression of reflection on inequalities and environmental injustices in the construction of environmental knowledge produces not only the de-politicisation of the issue reinforces the ecological dimension of the environmental issue, to the detriment of political, ethical and economic dimensions (HALUZA-DELAY, 2013; COSENZA; MARTINS, 2013).

\section{INTERTEXTUALITY IN CRITICAL DISCOURSE ANALYSIS}

Our starting point is Critical Discourse Analysis (CDA herein) (FAIRCLOUGH, 2001; FAIRCLOUGH, 2003) and the premise that discourse are forged in relationship with their macrosocial contexts of existence, how they change and thus inform their own social practices. Thus, through linguistic analysis, CDA reveals opaque power relations hegemonically formed in discourses. In our case, education is the social practice in question and teacher's discourses will be signified with respect to wider social relationship between environmental education and environmental justice.

Fairclough (2003) situates the role of language in the hegemonic struggle and assumes hegemony in late modernity ${ }^{6}$ as the dominance exerted by the power of one group over others, based more on consensus than on coercion or the use of force. This dominance, however, is always in unstable equilibrium and there are points of instability which lead to dispute for hegemony in discourse.

The notion of language as a space where there is a fight for hegemony in meanings is sustained, according to Fairclough (2003) by real subjects, experiencing things, building worlds, acting in discursive and social practices. In this way, social structures can be maintained or transformed. Since hegemony is seen in terms of relative permanence of articulations between social elements, there is an inherent possibility of dismantling and rearticulating these elements, which areperformed by human agency. Therefore, social agents, although socially constrained, do not have their actions totally determined, that is, they are endowed with relative freedom to establish innovative relations (RESENDE; RAMALHO, 2006).

In the notion of language as a hegemonic struggle, the question of power is always an issue. Likewise, hybridity, works in late modern society in a number of ways such as a strategy of resistance, a resource for dialogue, but also as strategy for domination (FAIRLOUGH 2003). Discursive hybridization processes, understood as the movement of a discoure or genre from one practice into another, implies its re-contextualization within them and take place between asymmetrically situated identities in relation to power. Relations with "other" discourses are all unequal relations, consisting of force vectors in the sense that the discourse of the "other" can be imposed from outside or used creatively as a resource for specific purposes. Hybridization, somehow, affects power: the original speech is recontextualized, takes part in something different, and so is caught in unforeseen discursive

\footnotetext{
${ }^{6}$ The late modernity is characterized by Giddens (2002) by a change in the nature of the world system involving a time-space compression acceleration forged from the early modernity crisis also named by the author as simple or industrial. It can be thought of as a period marked by the collapse of old certainties and by the production of new ways of positioning. Thus, the struggles for identity constructions are a salient feature of life in late modernity and constitute, for the theorists of the Critical Discourse Analysis (CDA), Chouliaraki and Fairclough (1999), identification issues in the speech: struggles to find a voice as part of battles to find an identity. Hence, social identities are constructed by means of classifications maintained by speech and thus, as they are discursively constructed, identities may also be challenged in the speech.
} 
trajectories of change for those whonow marked their place of origin. This, for Fairclough,is a basis for the ideological struggle in discourse (FAIRCLOUGH, 2003).

In the scope of this work, this critical understanding allows us to consider education as a process which is at the same time constrained by social structures and open to transformation towards its own new meanings and characteristics. In this sense, the school environment can also be thought of as ordered in two dimensions: (i) by a set of rules and regulations which seek to unify and define the action of its subjects and; (ii) by a complex web of social relationships between the individuals involved, including alliances and conflicts, imposition of norms and individual or collective transgression strategies and agreements. Thus, school process involve constant appropriation of spaces, standards, practices and knowledge, which shape school life.

Fairclough $(2001,2003)$ considers the relationship between discourse and the sociocultural world as a dynamic and always moving one. This allows for the transformative or reproductive character of social practices. To understand the process of change or stability in discoursethe analyst is concerned, on the one hand, with the particular characteristics of a specific event - analyzing it in its dual dimension of discursive practices (production process, circulation and interpretation) - and, on the other hand, with the nature of the social practice (connected withthe global and local socio-cultural context).

While trying to understand this process, the focus of this study lies with the intertextual aspect of production and interpretation of the discursive events analyzed, which were settled in a constant dialogue with a network of culturally available texts, for instance, texts studied throughout the project and/or present in their educational and social practice. Critical Discourse Analysis believes that every text is composed of elements from other texts, updates and responds to previous texts, while it is oriented and anticipated by texts that will follow (FAIRCLOUGH, 2001).

In this way, intertextual analysis involves direct textual (written/oral) resources used by the teacher, for example, titles, lexical choices, and explicitly evaluative statements, as well as indirect resources, such as, certain syntactical structures, the construction of semantic structure, the resources to assumptions, denials and metadiscourses, mechanisms for putting into evidence or deleting certain facts, the establishment of causal links etc. According to Moita Lopes and Fabrício (2005), this complex relationship between resources - lexical, syntactic, semantic and inter-sentential levels -, is involved in the construction of an ideological perspective to the text.

We favor the dimension which concerns manifest intertextuality, that is, the ways in which other texts are explicitly marked in the textual surface, suggesting 1) the types of discourse, how they are represented and also their role in the text (discourse representation), 2) the proposals considered by their producers as something already established (presuppositions), 3) evasive, metaphoric expressions or passages which suggest belonging to another text or use of paraphrases (metadiscourse).

According to Fairclough, intertextuality also takes part in the ideological constitution of subjects. It has implications for the relationship between discourse and identity, as, to the author, a person not only incorporates other discourses, but is also involved in practices which challenges and restructures the politically and ideologically motivated discursive structures.

Based on the theoretical framework presented, we turn to the analysis of discursive events, mapping discourses on environmental education and teacher's speech. We seek to understand which discourses about environmental conflict circulate in the teacher's recontextualizations of the thematic social practice (socio-environmental conflict) into educational practices. Some questions guide our view: How does the environmental conflict 
make sense in her pedagogical practice? Which discourses come into play when the teacher mentions teaching strategies for the treatment of environmental conflict in school? What discursive resources are used interactionally to show, emphasise, resize, or delete the socioenvironmental conflict? What links do these practices suggest between environmental conflict and justice?

\section{ENVIRONMENTAL JUSTICE AND SOCIO-ENVIRONMENTAL CONFLICT IN THE CLASSROOM: DISCOURSES ON THEORIES, CONTENT AND DIDATIC STRATEGIES}

The severity of environmental problems in the city demanded a formative ethical and political commitment to environmental justice processes aimed at students who, as residents of the outskirts of the city - some born there, others established there -, live through these stories of migration and experience precarious spaces and living conditions.

The work performed with the teacher involved two aspects. The first involved the collaboration between the teacher and the researcher who is first author of this paper throughout the year 2011 in reading activities, interpretation and discussion of science, science education and environmental education texts as resources for the production of new texts and reflections by the teacher about the pedagogic space of theme of energy and its local socio-environmental relations. This reflective exercise unfolded into new demands on the understanding of the environmental implications associated with the local exploitation of oil energy, which were negotiated with the teacher. Some features of the teacher training process, namely, the partnership established with the teacher, the commitment to mutual learning, the information search in social contexts and through relevant social actors, are consistent with premises of teaching for social justice (ZEICHNER, 2008) were inspired by Tobin's proposals of "cogenerative dialogue"(2010) ${ }^{7}$. Furthermore, Simonneaux and Legardez's ideas for didactic treatment of "socially acute questions"8 (SAQs) (2010) provided the principles for working with the teacher on the socio-epistemological examination of the our question as a potentially acute one, without directing them to specific teaching methods or objectives. Thus, the attempt to render the theme Energy: socio-environmental effects of oil exploration didactic and to embed in it a local environmental conflict were demands made to the teacher as part of (i) the project's objectives, (ii) particular research interests and ; (iii) the ethical-political commitment mentioned above.

The second aspect relates to the teacher's response to the suggestion. Her choice was a a conflictive situation in an area in which some of her students dwell. In the course of the work with the teacher, the notion of environment was constructed from a conflicting array of local socio-environmental problems in Macaé. In the course of these actions, the teacher planned and developed educational actions for her second year high school students, which

\footnotetext{
${ }^{7}$ The term is created by Tobin (2010) in the context of training studies, when the use of critical ethnography references, based on reflectivity and collaboration among teachers or between teachers and students in order to catalyze improvements in the quality of social encounters, as well as in educational institutional results.

${ }^{8}$ Socially Acute Questions, a term originally referred to by Simonneaux and Legardez (2010) (also referred to by the acronym SAQs) in didactic transposition process, are those which have the following characteristics: 1) they are social issues challenging social practices, require extensive debate, and may generate social conflicts, 2) they constitute controversies between different paradigms mobilizedby subjects from different disciplines or different political, cultural and social activitiY fields, 3) they are acutequestions in the knowledge to be taught.
} 
involved the didactic treatment of socio-environmental problems in Macaé and of the socioenvironmental conflict mentioned.

In an attempt to understand intertextual relationships, our focus was on the relationships that could be established between the teacher's discourse in relation to (i) textual material she had contact with during the work in the project and (ii) oral discourse of participants in the environmental conflict.

\section{Meanings produced in the context of discursive interactions}

Here we explore meanings which were produced in the first pedagogical activity developed by the teacher under the Project. It began with the request to students to produce a photographic image that best represented the social and/or local environmental effects of oil exploration. Iamges were then discussed in the classroom. Through this activity, the teacher aimed at knowing students' meanings of environmental degradation and at identifying possible environmental conflict.

In one of the images, offered by Carlos $^{9}$, two elements were in evidence: a city bus in the foreground and in the background, a monument of the city, built after the oil company establishment in the city. The bus and the monument are two semiotic elements which share a theme: the representation of a notion of progress, which involves changes in the landscape and modernization of transport.

Although the image leads to a developmentalist ideal, which minimizes the socioenvironmental problems and emphasises positive social effects of productive and technological activities (LAYRARGUES and LIMA, 2011), the exchanges below seem to have been able to challenge such ideal and produce new understandings towards issue of progress in Macaé.

FERNANDA: ... this image. I think it brought a very large development to the population, many outsiders and so on. And with that... somehow the city grew not so much according to the population, because we will take a bus and it's all crowded. We see that the situation is precarious, right?, and the price of the bus is very expensive.

TEACHER: But what your colleague said earlier is that transport in the city is good, goodquality, do you agree, disagree, how do you see it?

RAFAELA: I think ... you know what happens, the population complains too much too. One thing we can't complain about is the state of health and education. All schools have good food and great snacks. I say so because I have lunch at school and the food is delicious. Public hospitals are good, you may even have to wait a lot, but the appointments you know, you go there and that will solve your problem (...) So Macaé has health and sanitation, ok for the city, those are good points to the city.

TEACHER Our colleague here wanted to make a different consideration on sanitation.

FELIPE: but, guys, like, the city has no legal treatment for sewage, you see there are many neighborhoods that are so forgotten, for instance, nobody goes there, no one knows, just when elections are coming, they ask for votes, do something there, but nobody goes there to put a hydrometer... thereare some places there that you have to pull water out from wells, only by pumping, the water doesn't reach the houses, only with the help of pumps. There, in the [name of neighbourhood], the water in [name of neighbourhood] is black.

\footnotetext{
${ }^{9}$ All the names are fictitious.
} 
CARLOS: "So, we see that is one of the bad things on that side. This has a good side and a bad side as has been said here".

The cohesive marker ("somehow") to relativize the growth of the city and to talk about the precariousness of transport services. The teacher intervenes, uses the adversative conjunction "but" to include in the discussion the voice of the student who praised public transport in the city and start off a debate about conflicting perceptions. She used this intertext (metadiscourse) to enhance differences of viewpoints. Rafaela speaks up saying she was outraged by so many complaints. Her speech is challenged by the teacher, who calls Felipe to speak. He, in turn, questions the information on sanitation, adding new information about the neighborhood where he lives.

When questioning the lack of sanitation in the neighbourhood in question, Felipe challenges Rafaela by referring to meaningful social experiences of the living worlds of many students who are residents of this neighborhood into the school world. In such case, evidence is connected to these experiences, based on life contexts. Levinson (2006) considers that different experiences that people live through in the course of their lives influence their judgments and thus in controversial debates,

Fernanda, Felipe and Rafaela (re)described experiences in terms of new issues that extend the notion of environment. This may have contributed to the reformulation of Carlos's discourse who admits eventually, after the exchanges, negative aspects previously hidden.

The mediation offered by the teacher was vital as it favored the production of difference - as opposed to attempting to arrive at consensus - about the issues examined. That seems to have contributed to shed light on aspects which are not usually included in the discussion of such cases. In this way, it goes beyond hasty associations between technology, progress, social concern and quality of life.

The teacher's intertexts allude to emancipatory pedagogical trends of environmental education approaches which seek to implicate citizens in socially committed reflection and action. By stimulating students' to discuss their experiences in the classroom and opening up a significant time slot in her teaching, the teacher favours a pedagogical perspectives which values students active participation and allows them to construct themselves as social subjects, implicated in the environmental conflict. She acts like that by reframing the school curricula, which can be quite closed to the incorporation of students' experiences and to hearing their stories. Her approach does more than "starting from what students already know". By highlighting different views and exploring contextual aspects that relate to the socio-historical processes of occupation and changes in the place where they used to live by the oil industry, the teacher recognizes many of her students as victims of this process.

Therefore, it is important to note the teacher's intentions and actions directed at broadening the debate and at transforming the classroom into a collective space of knowledge production that is not marked by authority discourses and silenced voices. The methodology developed valued the dialogue and debate between students and the different discursive positions present in the images.

If a practice is challenged by several viewspoints, it may be more difficult to maintain the naturalization of hegemonic discourses. Under these conditions, according to Fairclough (2003), a conscious transforming practice can more easily develop. The exchanges exposed in this section present speeches which re-signifyhegemonic discourses (developmentalist, conservationists, pragmatic), creating new meanings identified with social experiences in which students are subjects. Hence, the exchanges exposed above help us to understand that there are no controversies per se. The notion of environment and the effects of energy exploitation in Macaé only become controversial when different judgments are produced and 
put into confrontation. In this direction, the mediation of the teacher may favor the fact that controversies are incorporated into the process of exchange and dialogue.

Ambivalence was also significantly involved in meaning making. The example which follows draws attention to the teacher's representations of the different perceptions about relationships between the increase in garbage in the city and the arrival of migrants:

I have here the speech of a municipal schoolemployee, born in Macaé and who is now at the age of 50 years. She says: "The city underwent a profound transformation with the arrival of the oil company. Before, there were no jobs for people. Now everyone gets a job." But she also says: "residents who come from other cities have no love for the place, but it's this place that guarantees their income" [...] they are outsiders, but they set no ties to the place. They can't like the city as they liked their city of origin and, at the first opportunity they have, they leave. And she adds that the arrival of these people here has caused the break up in ties between the former residents eventually. Her speech is like this: "the ties with the neighborhood are over. The principles of the former citizens ended.

The teacher here searches for new intertexts, as metadiscourse, and thus makes use of the speech of a resident born in the city to paraphrase and complexify ideas of blaming "outsiders, who have no love for the place, set no ties" to the city, "do not like the city, break ties and principles" established among the former residents. She paraphrases one resident's speech ad makes use of an older inhabitant's speech as a resource of authority and reliability. This significance in relation to migrants, mostly Northeastern, blamed for the pollution, in the teacher's speech, insinuates the socio-environmental problems experienced in Macaé in its relationship with environmental injustice and even environmental racism processes ${ }^{10}$.

Referring to migrants as "outsiders" contrasts with describing the macaenses, those who are "former residents". Such identity affirmation and difference marking imply, according to Silva (2013), including and excluding. Affirming the identity of the migrant means producing differences sustained by the discourse. Differentiations which demarcate boundaries between insiders (the former resident who cares and sets belonging ties to the place, who loves the place, who has principles) and outsiders (the new residents, who came other places).

\section{Meanings produced in the context of textual production}

In her text, entitled, "The STS approach and the study of controversial issues in a high school class" the teacher recounts her whole formative experience throughout the Project: the contents she addressed, her objectives, her teaching and assessment strategies. This text was subdivided by the teacher into four sections, namely: abstract, development, results report and considerations.

In her text, the conflict is quite central: the park is the subject of two sentences in the lines: (i) it covers the [name of the neighbourhood] and; (ii) it has been disputed by the residents, here referred to generically.

" [ ] the choice of the [name of the neighbourhood] was due to the fact that many
students in the class are residents of that neighbourhood. Also the controversy
surrounding the National Park, which covers [name of the neighbourhood] as buffer
zone, and which has been subject of dispute by the permanence of the surrounding
residents. Another justifiable reason would be the fact that the neighborhood is one
of the most common destinations for those who come to Macae in search of jobs,

${ }^{10}$ Environmental racism for Pacheco (2014) configures cases of "social and environmental injustices that fall
relentlessly on vulnerable ethnic groups and on other communities, discriminated by their 'race', origin or color". 
this population increase in the neighborhood, by neglect and omission of the authorities of the city, which "slumize" the place, turning it the point of greatest violence in the region.

The teacher highlights the [name of the neighbourhood] as a space marked by controversy. The controversy suggests tacit information about narratives that oppose progress to socio-environmental impacts and conflicting interests. Besides, she stresses: 1) a space of precariousness and socio-environmental degradation experienced of many of her students, 2) a space marked by a controversial dispute involving concrete subjects. She not only asks her students for these experiences, but also goes to [name of the neighbourhood] in order to meet them where they live: she visits the neighborhood, takes photographs, reads about it, interview people who belong to local social collectives, participates in community meetings. In her career, she sought to create pedagogical approaches that seek to bring the "neighborhood needs" and stories of these needs into the classroom:

Seeking to raise more knowledge of social and environmental problems arising from the oil industry, I made availaboe to students a collection of texts, slide shows, movies and pictures to the student (...) At a later time, I invited "Paula", a graduate student, who author of [these] texts analyzed by students, who in partnership with "Carla", a undergraduate student, gave a lecture on the theme: "criminalization of the residents of the [name of the neighbourhood] due to the illegal occupation of the environmental protection área (...) This moment also included the presence and participation of Professor "Edgar" from the Law Faculty, with an emphasis on socio-environmental, rural and urban conflicts.

In these segments, there is a direct discursive representation to refer to the texts used with the students. Besides, the names of the lecturers and the institutions they represent were explicitly nominated. This is a strategy that gives credibility and force to her text. Indeed, for Fairclough (2001), the higher the demarcation of the discourse, the larger its illocutionary force in texts.

The teacher also seems to use these representations to draw attention to the methodological strategies (lecture, drama, video, role play) used with the students and to suggest those as innovative pedagogical approaches:

In the class that followed the lecture, a proposal was made to students to draw up a role play activity addressing: 1-The conflict experienced by a resident family of [name of the neighbourhood] and later inhabitants of the occupied area, 2- The possibilities and impossibilities of [name of the neighbourhood] urbanization and the challenge to maintain naturepreserved. (...) As the final stage of the work, it was proposed to students organizing a video.

In the fictional story, which supports the role play activity, the teacher tells the story of a family that comes to the city from Northeastern Brazil, believing in "employment opportunities in activities related to the offshore oil production chain "and the"prospects for good jobs, good wages, and healthy life quality, with housing, education and health guarantees." Such family "Queiroz" is living in the [name of the neighbourhood] on the outskirts of the city "as an alternative to the high prices charged in real estate in prime areas of the city." In her speech she identifies the social actors who live in poverty and precariousness in the community where there is a socio-environmental conflict. They are described as a "disadvantaged population," located in "illegal and improper area for housing," and threatened to be "evicted from their homes"; the family was "constantly affected by health problems" as they dwelled in a neighborhood where "there is no basic sanitation, as treated water, sewer and regular garbage collection, neither lighting or transport." 
Her choices admit intertextual relations with environmental education approaches identified with environmental justice (HALUZA-DELAY, 2013), in which there is also a commitment to social experiences of the subjects and to providing students with opportunities to understand and to place themselves before controversial topics and sociallyacute questions.

However, our analysis suggest that despite proposing an engaged pedagogical approach - that was contextualized in environmental degradation processes which are part of many of her students'lives -, the teacher minimizes the political causes and consequences of such processes in her discourse. In other words, her attempt to include the socioenvironmental conflict in her teaching did not fully explore issues such as social and environmental inequality, disproportionate distribution of services and benefits, or problematized the impacts of the oil industry growth. Although the didactic treatment of the conflict has pointed to particular causes, actors and scenes which animate such a conflict, her discourse (and practice) did not problematize how certain groups end up suffering more than others.

\section{FINAL CONSIDERATIONS}

The analysis suggests that by framing her teaching around the socio-environmental conflict, the teacher established ambivalent relations between conservative and emancipatory discourses of science/biology education - which are themselves controversial topics -, and environmental education.

The results point to the need for strengthening environmental justice and socioenvironmental conflicts in the didactic treatment of environmental issues in school as a possibility to achieve goals committed with emancipatory educational practices.

The teacher's meanings about the socio-environmental conflict did not fully adhere to environmental justice perspectives in so far as socio-environmental conditions of oppression and community protagonism were not emphasized. Nonetheless, the incorporation of socioenvironmental conflict in her teaching materialized a discursive change niche which challenged traditional approaches to environmental hegemonic educational practices, which contribute to the erasure of socio-environmental conflicts.

From the perspective of the CDA, the different discourses (including the researcher's), displayed during project were read by the teacher, under the condition of "interpreter". For Fairclough (2001, p. 173), interpreters are more than discourse subjects: they are also social subjects, with particular social experiences accumulated and with variably oriented discourses for multiple functions of social life. Such variables affect the ways in which they will interpret particular discourses. Also, some interpreters are resistant to a greater or lesser extent. Hence, the formation of a hybrid educational practice (of conservative reference at times and emancipatory in others) by the teacher can be considered as a strategy for dialogue in the context of tensions between the actions taken and the limits exposed above.

According to Fairclough, the origins and the immediate motivations for change in the discursive event lie in questioning the conventions. Interpreters try to solve what he calls "dilemmas", being innovative or creative or adapting to existing conventions in new ways and thus contributing to the discursive change. The discourses hybridization is therefore a creative option.

Thoughout the project the teacher had to manage between two different orientations: (i) giving visibility to experiences of environmental degradation and inequality as well as experiences of local community struggles, as suggested by the project, and; (ii) following the state curriculum, which limited her options with respect to choices of both content and 
pedagogical approaches. This was the dilemma with which the teacher had to deal. Thus, although her discursive shifts cannot be characterised as radical critical transgression, the process was marked by attemps of border crossing between traditional practices sanctioned by the official curriculum and the new possibilities the project confronted her with. In this way, we believe that the contribution of this study is to expose the complexity of the conditions which are involved in discursive change and social change

\section{REFERENCES}

ACSELRAD, H. MELLO, C.C. (2009). A. O que é Justiça Ambiental. Rio de Janeiro: Garamond.

CHOULIARAKI, L.; FAIRCLOUGH, N. Discourse in Late Modernity: Rethinking Critical Discourse Analysis. Edinburgh: Edinburgh University Press, 1999.

BULLARD, R. Enfrentando o Racismo Ambiental no Século XXI. In: ACSELRAD, H; HERCULANO, S.; PÁDUA, J. A. Justiça Ambiental e Cidadania. Rio de Janeiro: Relume Dumará: Fundação Ford. p. 41-68. 2004.

COSENZA, A.; MARTINS, I. Controvérsias socioambientais no contexto da construção de sentidos sobre relações entre energia e ambiente na escola. In: Revista Brasileira de Pesquisa em Educação em Ciências, Vol. 13, N.03, p. 73-94, 2013.

FAIRCLOUGH, N. Analysing Discourse: Textual analysis for social research. London: Routledge. 2003.

FAIRCLOUGH, N. Discurso e Mudança Social. Brasília: Editora da Universidade de Brasília. 2001.

FILHO, W. M.; RORIZ, J. E. ; SILVIERA, A. C. (2011) Poluição cívica: Criminalização do Bairro Lagomar no Município de Macaé e ajustamentos de conduta. In: Impactos sociais, ambientais e urbanos das atividades petrolíferas: o caso de Macaé. Disponível em: http://www.uff.br/macaeimpacto/OFICINAMACAE/pdf/34_WilsonMadeira.pdf. Acessado em $\underline{05 / 07 / 2011}$

GIDDENS, A. Modernidade e Identidade. 1.ed. Rio de Janeiro: Editora Zahar, 2002.

HALUZA-DELAY, R. Educating for Environmental Justice. In: STEVENSON, R. B., BRODY, M. ; DILLON, J.; WALS, A. E. J. International Handbook of Research on Environmental Education. New York: Routledge: p. 394-403, 2013.

LAYRARGUES, P. P.; LIMA, G. Mapeando as Macro-tendências político-pedagógicas da Educação Ambiental no Brasil. In: Anais do VI Encontro Pesquisa em Educação Ambiental. USP: Ribeirão Preto, p. 1-15 (CD-ROM). 2011.

LEVINSON, R. Towards a Theoretical Framework for Teaching Controversial Socio-scientific Issues. In: International Journal of Science Education. Vol. 28, No. 10, p. 1201-1224. 2006.

MOITA LOPES, L. P; e FABRÍCIO, B. F. Discursos como arma de guerra: um posicionamento ocidentalista na construção da alteridade. Em: Delta, número especial 21, p. 239-283. 2005.

RESENDE, V. M.; RAMALHO, V. Análise de Discurso Crítica. São Paulo: Contexto, 2006SILVA, T. T. A produção social da identidade e da diferença. In: SILVA, T. T. (Org.) Identidade e Diferença: a perspectiva dos estudos culturais. 13. ed. Petrópolis, RJ: Vozes, 2013. 
SIMONNEAUX, J.; LEGARDEZ, A. The epistemological and didactical challenges involved in Teaching Socially Acute questions. The example of Globalization. In: Journal of Social Science Education. Volumen 9, number 4, p. 24-35, 2010.

TOBIN, K. La colaboración para transformar y reproducir la didáctica de lãs ciencias. In: Enseñanza de las Ciencias, Vol. 28, p. 301-313, 2010.

ZEICHNER, K. Formação de professores para a justiça social em tempos de incerteza e desigualdades crescentes. In: ZEICHNER, K. M; DINIZ, PEREIRA, J. E. (orgs.) Justiça social: desafios para a formação de professores. Belo Horizonte: Autêntica Editora, p.11-34, 2008. 